\title{
Building up Prestasi Belajar Siswa Dengan Media Inovatif
}

\author{
Anwar Sewang \\ STAIN Majene, West Sulawesi, Indonesia, \\ *email: sewanganwar@yahoo.com \\ Received: 07-08-2021; Reviewed:16-08-2021; Accepted: 21-08-2021
}

\begin{abstract}
Abstrak
Penelitian ini bertujuan untuk mengetahui keefektifan penggunaan media gambar dalam pembelajaran pendidikan kewarganegaraan di SMAN 4 Polewali Kabupaten Polewali Mandar. Jenis penelitian ini adalah penelitian eksperimen dengan analisis statistik inferensial menggunakan teknik uji-t. Populasi dalam penelitian ini adalah siswa kelas X SMAN 4 Polewali yang berjumlah 70 siswa dengan teknik total sampling. Pengambilan data dilakukan melalui teknik dokumentasi dan tes. Hasil penelitian menunjukkan bahwa terdapat perbedaan prestasi belajar siswa yang menggunakan media gambar dan tidak menggunakan media gambar, dengan rata-rata prestasi belajar siswa kelompok eksperimen adalah 80,35 sedangkan prestasi belajar siswa kelompok kontrol rata-rata 60,95.
\end{abstract}

Kata kunci: Efektivitas, Gambar, Prestasi

\section{Abstract}

This study aims to determine the effectiveness of using image media in learning citizenship education at SMAN 4 Polewali, Polewali Mandar Regency. This type of research is experimental research with inferential statistical analysis using t-test technique. The population in this study were students of class X SMAN 4 Polewali totaling 70 students with a total sampling technique. Data retrieval is done through documentation and test techniques. The results showed that there were differences in student achievement using picture media and those not using picture media, with the experimental group's average student achievement being 80.35 while the control group's student achievement was an average of 60.95 .

\section{Keywords: Effectiveness, Picture, Achievement}

\section{PENDAHULUAN}

Keberadaan media dalam proses belajar mengajar sangat menentukan pencapaian tujuan pembelajaran, termasuk media gambar. Media gambar terutama pada mata pelajaran Kewarganegaraan sangat dibutuhkan mengingat kemampuan berpikir siswa perlu banyak dilandasi dengan hal-hal yang bersifat konkrit. Berdasarkan hal di atas, berarti pembelajaran Kewarganegaraan di kelas akan lebih efektif dan mudah dimengerti jika konsep Kewarganegaraan direalisasikan ke dalam bentuk yang nyata. Dengan demikian keberadaan media dalam pengajaran Kewarganegaraan akan membantu siswa dan guru. Gambar sebagai salah satu media pengajaran adalah merupakan jawaban terhadap permasalahan dari keterbatasan waktu, biaya dan sulitnya mengungjungi lokasi/obyek pelajaran. Banyak hal yang dapat disampaikan melalui perantaraan media gambar dalam proses pembelajaran termasuk mata pelajaran Kewarganegaraan.

Gambar termasuk salah satu media visual yang dapat digunakan dalam membantu penyampaian materi. Selain sederhana gambar juga mudah pengadaannya, Melalui penggunaan gambar akan menghindarkan kesalah pahaman dan salah pengertian antara yang dimaksud oleh 
guru sebagai penyaji dengan siswa sebagai penerima di dalam proses pembelajaran di kelas. Penggunaan media ini dapat digunakan dalam bidang Kewarganegaraan karena dengan media tersebut siswa dapat melihat dan mengamati secara langsung apa yang dilihat, sehingga pemahaman terhadap makna yang dikandung dalam materi pelajaran yang disajikan akan lebih bermakna dan dimengerti, hanya saja keberhasilan dalam penggunaan media gambar tersebut terletak pada "Bagaimana guru memanfaatkan media dalam proses pembelajaran, yang disesuaikan dengan materi dan tujuan yang ingin dicapai". Di samping itu penggunaan media gambar diharapkan dapat memotivasi siswa untuk mengikuti pembelajaran Kewarganegaraan yang pada akhirnya dapat menjadi pemacu dalam meningkatkan prestasi belajar siswa khususnya dalam mata pelajaran Kewarganegaraan kelas $\mathrm{X}$ di SMA Negeri 4 Polewali. Media gambar yang hendaknya dipergunakan dalam pengajaran Kewarganegaraan antara lain peta dunia dan Indonesia, foto/gambar pahlawan dan tokoh-tokoh hak azasi manusia, tokoh politik, negarawan struktur pemerintahan, skema pelaksanaan Pemilu, struktur pemerintahan dan sebagainya.

Pemikiran inilah yang merupakan dasar berpijak bagi peneliti sehingga termotivasi melakukan penelitian yang berhubungan dengan media gambar dalam upaya meningkatkan prestasi belajar siswa dalam mata pelajaran Kewarganegaraan. Yang menjadi permasalahan pokok dalam penelitian ini adalah : Apakah ada perbedaan prestasi belajar siswa kelas X yang diajar dengan menggunakan media bagan struktur pemerintahan dengan yang tidak menggunakan media gambar pada kompetensi dasar hakikat bangsa dan negara dalam mata pelajaran Kewarganegaraan. Tujuan yang ingin dicapai dalam penelitian ini adalah: untuk mengetahui perbedaan prestasi belajar siswa yang diajar dengan menggunakan media bagan struktur pemerintahan dengan yang tidak menggunakan media gambar mata pelajaran Kewarganegaraan pada siswa kelas X di SMA Negeri 4 Polewali Kabupaten Polewali Mandar.

Manfaat dari hasil penelitian ini pada dasarnya sebagai berikut. (1) Memotivasi guru dan siswa untuk menggunakan media gambar dalam pengajaran Kewarganegaraan. (2) Dapat menjadi masukan bagi semua pihak yang berkecimpung dalam dunia pendidikan pada umumnya dan guru Kewarganegaraan pada khususunya.

Sedangkan hipotesis penelitian adalah "Ada perbedaan prestasi belajar siswa kelas X yang diajar dengan menggunakan media bagan struktur pemerintahan dengan prestasi belajar siswa yang diajar tanpa menggunakan media bagan struktur pemerintahan."

Media berasal dari bahasa Latin yang merupakan bentuk jamak dari“medium”secara harfiah berarti perantara atau pengantar. Makna pada umumnya adalah segala sesuatu yang dapat menyalurkan informasi dari sumber kepada penerima informasi. Istilah media ini populer dalam bidang komunikasi. Proses belajar mengajar adalah proses komunikasi, sehingga media yang digunakan dalam pembelajaran disebut media pembelajaran.

Banyak ahli memberikan batasan tentang media pembelajaran. AECT mengatakan bahwa media pembelajaran adalah segala sesuatu yang digunakan orang untuk menyalurkan pesan Gagne mengatakan bahwa media sebagai jenis komponen dalam lingkungan siswa yang dapat merangsang siswa untuk belajar. Sedangkan Briggs mengartikan bahwa media sebagai alat untuk memberikan perangsang bagi siswa agar terjadi proses belajar. Selanjutnya Mc. Luchan dalam John D. Latuheru (1988:23) menjelaskan pengertian media adalah sarana yang juga disebut chanel (saluran), karena pada hakekatnya media memperluas atau memperpanjang kemampuan manusia untuk merasakan, mendengar, dan melihat dalam batas-batas jarak, ruang, dan waktu yang hampir tidak terbatas lagi. 
Definisi tentang media, diajukan pula oleh Yusuf Hadi Miarso dalam Hartono, dkk (1993:27) bahwa media adalah segala sesuatu yang dapat merangsang terjadinya proses belajar pada diri siswa. Sependapat dengan itu, Gagne dalam Soekartawi, dkk (1995:72) menyatakan bahwa "media adalah komponen sumber belajar yang dapat merangsang siswa untuk belajar ". Sementara itu Briggs juga dalam Hartono, dkk. (1993:28) menyatakan media sebagai "wahana fisik yang mengandung materi Instruksional.”

Dari beberapa pengertian yang dikemukakan oleh para ahli maka, dapat diartikan bahwa media pembelajaran adalah meliputi alat bantu guru dalam mengajar serta sarana pembawa pesan dari sumber belajar ke penerima pesan belajar (siswa). Sebagai penyaji dan penyalur pesan, media belajar dalam hal-hal tertentu, bisa mewakili guru menyajikan informasi belajar kepada siswa. Jika program media itu didesain dan dikembangkan secara baik, maka fungsi itu dapat diperankan oleh media meskipun tanpa keberadaan guru. Peranan media semakin meningkat ini sering menimbulkan kekhawatiran bagi guru. Namun sebenarnya hal itu tidak perlu terjadi, seandainya kita menyadari betapa masih banyak dan beratnya peran guru yang lain. Memberikan perhatian dan bimbingan secara individual kepada siswa, merupakan tugas penting guru yang terkadang kurang mendapat perhatian. Hal ini mungkin karena waktu yang ada telah banyak tersita untuk tugas menyajikan materi pelajaran. Kondisi ini akan terus terjadi pada diri seorang guru selama ada anggapan bahwa guru adalah satu-satunya sumber belajar bagi siswa. Padahal jika seorang guru dapat memanfaatkan berbagai sumber belajar (media) belajar secara baik, maka guru dapat berbagi peran dengan media. Percayakanlan sebahagian peran kepada media pembelajaran. Dengan begitu, peran guru akan lebih mengarah kepada guru sebagai manajer pembelajaran yang tugasnya memfasilitasi siswa dalam belajar. Tanggung jawab utama manajer pembelajaran adalah menciptakan kondisi sedemikian rupa agar siswa dapat belajar. Proses kegiatan akan terjadi jika siswa dapat berinteraksi dengan berbagai sumber belajar.

Manfaat Media Pendidikan: Teknologi pengajaran sebagai bagian integral dari pendidikan memerlukan upaya manusia (guru dan tenaga kependidikan atau sekelompok tenaga profesional lainnya) yang sifatnya menyeluruh. Oleh karena itu, upaya memanfaatkan media dalam pendidikan dapat mengkaji kegiatan mengajar dan belajar berdasarkan pendekatan teknologis memerlukan keterampilan tersendiri. Karena itu, upaya pendidikan diarahkan untuk mencapai tujuan pendidikan yang bermutu secara kuantitatif. Danim (1993:10-12) mengemukakan beberapa manfaat media sebagai beriku. Media teknologi pendidikan membuat pendidikan lebih produktif. Media teknologi pendidikan menunjang pengajaran individual, atau dengan kata lain, memungkinkan penerapan individualisme dalam kegiatan pengajaran. Media teknologi pengajaran membuat kegiatan pengajaran lebih ilmiah. Media teknologi pendidikan dapat membuat pengajaran lebih "Power Full". Media teknologi pendidikan dapat membuat kegiatan belajar mengajar lebih" Immediate". Media pendidikan dapat membuat percepatan pendidikan. Selanjutnya pendapat Donald yang dikutip Danim (1993:12) menyatakan bahwa, "Manfaat media teknologi pendidikan, yaitu: meningkatkan produktifitas pendidikan: memberikan kemungkinan kemungkinan kegiatan pengajaran bersifat individual, memberi dasar yang lebih dinamis terhadap pendidikan, pengajaran yang lebih mantap, memungkinkan belajar seketika dan penyajian pendidikan yang lebih luas". Kemudian Arif Sadiman (1993:183-195) membagi dua pemanfaatan media sebagai berikut ini. Pemanfaatan media dalam situasi kelas (Classroom setting). Dalam tatanan (setting) ini media pembelajaran dimanfaatkan untuk menunjang tercapainya tujuan tertentu dan pemanfaatannya dipadukan dengan proses belajar mengajar dalam situasi kelas. Pemanfaatan media di luar situasi kelas terdiri atas pemanfaatan secara bebas, pemanfaatan media secara terkontrol, serta pemanfaatan media secara perorangan, kelompok atau masalah. 
Dari rumusan di atas, dapat ditarik kesimpulan bahwa manfaat media dalam proses belajar mengajar dapat menunjang pengajaran individual, membuat pengajaran lebih efektif, meningkatkan belajar seketika dan penyajian pendidikan lebih luas, menunjang tercapainya tujuan. Manfaat media secara umum adalah memperlancar interaksi antar guru dan siswa dalam kegiatan belajar mengajar sehingga pembelajaran akan lebih efektif dan efisien. Secara khusus, media pelajaran bermanfaat sebagai berikut: (1) Penyampaian materi pelajaran dapat diseragamkan. Banyak hal yang mungkin terjadi perbedaan penafsiran guru terhadap materi tertentu. namun dengan media pelajaran, perbedaan itu dapat diseragamkan dalam penerimaan informasi. Artinya media dapat mengurangi terjadinya kesenjangan informasi diantara siswa dan guru di manapun berada. (2) Proses pembelajaran menjadi jelas dan menarik. Media dapat menampilkan informasi melalui suara, gambar, gerakan dan warna yang menarik baik alamiah maupun manipulasi. Materi pelajaran yang dikemas melalui program media, akan lebih jelas, lengkap, dan menarik siswa. Dengan demikian media bahkan materi sajian dapat merangsang minat siswa, membangkitkan rasa keingintahuan siswa baik secara fisik, maupun emosional siswa. (3) Proses pembelajaran menjadi lebih interaktif. Media pelajaran jika dipilih dan dirancang dengan baik, dapat membantu guru dan siswa melakukan komunikasi dua arah secara aktif. Seorang guru tanpa media pelajaran maka guru akan cenderung berkomunikasi satu arah kepada siswa. Namun dengan media pelajaran, guru dapat mengatur kelas sehingga bukan hanya guru yang aktif tetapi juga siswa saling berinteraksi. (4) Efisiensi dalam waktu dan tenaga. Guru sering mengeluh kekurangan waktu dalam menjelaskan materi tertentu. Dengan bantuan media pelajaran, seorang guru tidak perlu menjelaskan dengan waktu yang lama, karena dengan media pelajaran, banyak hal yang dengan mudah dapat dipahami siswa dalam waktu yang singkat oleh karena siswa dapat melihat, mendengar secara lansung. (5) Meningkatkan kualitas hasil belajar siswa. Penggunaan media pelajaran bukan hanya membuat proses belajar lebih efisien, tetapi juga membantu siswa menyerap materi pelajaran lebih mendalam dan utuh. Bila hanya dengan mendengarkan materi verbal dari guru saja, siswa mungkin kurang dapat memahami pelajaran secara baik. Tetapi jika hal itu diperkaya dengan kegiatan melihat, menyentuh, merasakan atau mengalami sendiri melalui media pelajaran, maka pemahaman siswa pasti akan lebih baik. (6) Media memungkinkan proses belajar dapat dilakukan di mana saja dan kapan saja. Media pembelajaran dapat dirancang sedemikian rupa sehingga siswa dapat melakukan kegiatan belajar secara lebih leluasa, kapanpun dan di manapun, tanpa tergantung pada keberadaan seorang guru. Program pembelajaran dengan komputer memungkinkan siswa dapat melakukan kegiatan pembelajaran secara mandiri, tanpa terikat oleh waktu dan tempat. Penggunaan media akan menyadarkan siswa betapa banyak sumber-sumber belajar yang dapat mereka manfaatkan untuk belajar. (7) Media dapat menumbuhkan sikap positip siswa terhadap materi pelajaran dan proses belajar. Dengan media, pembelajaran lebih menarik sehingga mendorong siswa untuk mencintai ilmu pengetahuan gemar mencari sendiri sumber-sumber belajar ilmu pengetahuan. Kebiasaan siswa untuk mencari sumber-sumber pengetahuan tersebut akan bisa menanamkan sikap kepada siswa untuk senantiasa berinisiatif mencari berbagai sumber belajar yang dibutuhkan. (8) Merubah peran guru ke arah positif dan produktif. Dengan memanfaatkan media secara baik, seorang guru bukan lagi menjadi satu-satunya sumber belajar bagi siswa. Seorang guru tidak perlu menjelaskan seluruh materi pelajaran, karena bisa berbagi peran dengan media. Dengan demikian, guru akan bisa lebih banyak memiliki waktu untuk memberi perhatian kepada aspek-aspek edukatif lainnya, seperti membantu kesulitan belajar siswa, pembentukan kepribadian, memotivasi belajar dan lain-lain. (9) Media dapat membuat pelajaran abstrak menjadi konkrit. Misalnya arus lisrik dapat dijelaskan dengan gambar konkrit. (10) Informasi pelajaran yang disajikan dengan media yang tepat akan memberikan kesan mendalam dan lebih lama tersimpan pada diri siswa. Dengan media, panca indera siswa tidak hanya monoton pada pendengaran atau penglihatan saja akan tetapi melalui media, panca indera siswa dapat berfungsi secara maksimal yang akan membantu mengingat. 


\section{Literatur}

\section{Media Pendidikan}

Pada prinsipnya media pendidikan merupakan pelengkap yang dapat membantu guru menciptakan dorongan psikologis untuk belajar pada siswa-siswa. Perlu tidaknya media pendidikan digunakan tergantung dapat tidaknya media pendidikan tersebut memenuhi kriteria utama. Kriteria utama yang dipenuhi oleh media pengajaran menurut Suparno (1988:126) adalah: motivasi, konsentrasi, reaksi, penyelenggaraan dan pengertian atau pengulangan yang diinginkan. Dapat meningkatkan pengertian pokok pelajaran. Sebuah media pendidikan yang direncanakan secara tepat, dapat pula memberikan pengertian yang tepat. Media pendidikan ini dapat berupa bagian atau model tentang konsep materi pelajaran yang akan ditetapkan kepada siswa. Dengan menggunakan media pendidikan maka pelajaran yang disajikan dalam proses pembelajaran tidak hanya diterima oleh siswa secara verbilitas tetapi dapat pula dimengerti dengan nyata. Dapat mencapai tujuan yang sebenarnya. Media pendidikan harus selalu diarahkan pada tujuan khusus daripada pelajaran yang direncanakan dalam bentuk yang dapat mencapai tujuan yang sebaik-baiknya. Dapat menimbulkan minat terhadap mata pelajaran yang penting. Perlu disadari bahwa media pengajaran merupakan alat, selain harus menarik dan menyenangkan, media pendidikan harus pula merangsang minat terhadap mata pelajaran itu sendiri lebih-lebih daripada minat terhadap alat-alat pelajarannya (motivasi, tujuan, konsentrasi dan reaksi). Meningkatkan kegairahan belajar. Media pembelajaran yang baik hendaknya dapat meningkatkan kegairahan belajar siswa dan membantu siswa memahami konsep materi pelajaran dalam proses belajar mengajar di sekolah. Dari uraian di atas dapat disimpulkan bahwa kriteria pemilihan media pendidikan diusahakan dapat meningkatkan pengertian pokok pelajaran, mendapat tujuan yang sebenarnya, menimbulkan minat terhadap mata pelajaran yang penting, serta dapat meningkatkan kegairahan belajar siswa.

Gambar adalah merupakan bagian dari media pendidikan, apabila gambar itu dimanfaatkan dalam dunia pendidikan. Media adalah suatu alat atau bahan yang dipakai sebagai saluran untuk menyampaikan pesan atau informasi dari komunikator kepada komunikan atau pemberi kepada penerima informasi. Oemar Hamalik (1989: 43) menyatakan bahwa" Gambar diam adalah foto atau sejenisnya yang menampakkan orang, tempat atau benda", sedangkan Soetina Soewondo (1978: 31) menyatakan bahwa "Gambar (grafik aids) ialah media yang memiliki kekuatan untuk mengajar atau membelajarkan, merupakan alat alat pengajaran yang diamati / dilihat), dan bersifat menyederhanakan ide-ide dan fakta-fakta". Berdasarkan uraian di atas maka dapat disimpulkan bahwa, media gambar adalah suatu fakta-fakta dan gagasan- gagasan suara jelas dan kuat melalui perpaduan antara kata-kata dan gambar.

\section{Klasifikasi Media Gambar}

Media gambar dapat diklasifikasikan atas beberapa macam sebagai berikut.

a) Berdasarkan cara pembuatannya berikut.

Dilihat dari cara pembuatannya, gambar dapat di bedakan atas dua macam yaitu, sebagai

(1) Gambar fotografi merupakan sumber yang di peroleh dengan cara memotret obyek Nana Sudjana (1990:77) "Memotret pada dasarnya menggambar dengan menggunakan cahaya. Dengan demikian memotret pada prinsipnya adalah seni grafika yang dapat menghasilkan gambar gambar objek yang realistis, alamiah dengan rincian persis aslinya".

(2) Gambar tangan, biasanya dilakukan oleh seorang guru apabila dia tidak memperoleh gambar fotografi. Gambar yang dibuat harus sesuai dengan materi pelajaran yang disediakan. 
b) Berdasarkan ukurannya.

Dilihat dari ukurannya, gambar dapat dibedakan atas 3 macam yaitu:

(i) gambar ukuran besar, dimaksudkan untuk dimanfaatkan pada kelompok besar atau dalam bentuk klasikal. Gambar ukuran besar ini, esensinya adalah bahwa gambar tersebut bila dilihat dengan jelas dan terang alam kondisi proses belajar mengajar di kelas.

(ii) gambar ukuran sedang, digunakan pada kelompok kecil biasanya terdiri dari 3 sampai 8 orang.

(iii) gambar ukuran kecil, untuk digunakan secara individual. Dari beberapa penjelasan tentang gambar tersebut di atas, maka di dalam pemanfaatan gambar sebagai media pembelajaran, hendaknya guru mempertimbangkan berbagai aspek sehingga dengan gambar tersebut dapat memberikan nilai lebih dalam proses belajar mengajar. (3) Pemanfaatan Media Gambar dalam Proses Pembelajaran Kewarganegaraan. Media gambar adalah bagian dari media pendidikan yang bisa dimanfaatkan dalam proses belajar mengajar dan memiliki fungsi yang amat penting. Adapun fungsi dari media gambar seperti yang dikemukakan oleh Derek Rowntrie dalam dientje Borman Rumampuk (1988:68) yaitu sebagai berikut. Engage the student motivation (membangkitkan motivasi belajar) recall earlier learning (mengulang apa yang telah dipelajari)

active the student's response (Mengaktifkan respon murid) provide new learning stimuli (Menyediakan stimulus belajar) rive speedy feedback (memberikan balikan dengan cepat segera) Encourage appropriate pratice (menggalakkan latihan yang serasi). Berdasarkan uraian tersebut, maka media gambar pada khususnya dan media pada umumnya memiliki fungsi sebagai berikut, seperti yang dikutip pendapat yang diajukan Dientje Borman Romampuk (1988:70) yaitu sebagai berikut.

- Dapat membangkitkan motivasi belajar siswa.

- Dapat membentuk konsep abstrak.

- Dapat mengatasi batas-batas ruangan kelas.

- Dapat mengatasi pengalaman pribadi siswa.

- Dapat menampilkan objek yang terlalu kecil untuk dapa diamati secara langsung.

- Dapat menampilkan objek yang berbahaya atau terlalu besar sehingga tidak memungkinkan untuk dibawa di kelas.

- Dapat menyediakan informasi belajar secara konsisten.

- Dapat meyajikan pesan secara serempak.

- Dapat mengatasi pengamatan objek yang sangat kompleks.

- Dapat memberikan perhatian.

\section{Kelebihan dan Keterbatasan Media Gambar}

Gambar sebagai alat bantu pengajaran dalam proses pembelajaran mempunyai kelebihankelebihan dan keterbatasan-keterbatasan. Oemar Hamalik (1989: 64-65) mengutarakan kelebihankelebihan media gambar sebagai berikut. Gambar bersifat konkrit, melalui gambar siswa dapat melihat dengan jelas sesuatu yang sedang dibicarakan atau didiskusikan dalam kelas, sesuatu persoalan dapat dijelaskan dengan gambar selain penjelasan dengan kata-kata. Gambar membatasi waktu dan ruang. Gambar-gambar merupakan penjelasan dari benda-benda yang sebenarnya yang kerap kali tak mungkin dilihat karena letaknya. Gambar membatasi kekurangan daya mampu panca indera manusia, benda-benda yang kecil tidak dapat dilihat oleh mata, dapat dibuat fotografinya sehingga dengan jelas dapat dilihat/diamati. Dapat digunakan untuk menjelaskan sesuatu masalah, karena itu bernilai terhadap semua pelajaran di sekolah. Gambar-gambar mudah didapat dan murah. Untuk sekolah yang dananya terbatas apalagi yang sama sekali tak mampu, gambar bernilai 
ekonomis, menguntungkan dan meringankan beban sekolah. Mudah digunakan baik untuk perorangan maupun kelompok siswa. Satu gambar dapat dilihat oleh seluruh kelas, bahkan seluruh sekolah. Selain kelebihan-kelebihan dari gambar seperti yang tersebut pada uraian di atas, maka gambar mempunyai keterbatasan, antara lain sebagai berikut. Kadang-kadang terlalu kecil ukurannya untuk digunakan pada kelompok siswa yang cukup besar. Memang suatu gambar dapat diperbesar, tetapi hal ini tentu memerlukan suatu proses dan memerlukan biaya yang cukup besar pula. Pada umumnya hanya dua dimensi saja yang tampak pada gambar, sedangkan dimensi lainnya tidak jelas. Tidak dapat memperlihatkan suatu pola gerakan secara utuh untuk suatu gambar dalam suatu urutan peristiwa pada pola gerak tertentu. Gambar hanya menekankan persepsi indera mata saja, dan tanggapan biasa dapat berbeda terhadap gambar yang sama. Demikianlah uraian tentang penggunaan media gambar dalam proses pemebelajaran. Berdasarkan uraian tersebut di atas nyatalah bagi kita bahwa media gambar sangat bermanfaat dalam membantu proses pembelajaran, walaupun media gambar memiliki beberapa keterbatasan.

Penelitian ini adalah penelitian eksperimen yang meneliti perbedaan antara prestasi belajar siswa yang diajar dengan menggunakan media bagan struktur pemerintahan dan yang tidak menggunakan media bagan struktur pemerintahan siswa kelas X Kompetensi dasar Hakikat bangsa dan negara mata pelajaran Kewarganegaraan tahun pelajaran 2020-2021 di SMA Negeri 4 Polewali Kabupaten Polewali Mandar.

\section{Metode} berikut :

Teknik analisis data dalam penelitian ini meggunakan teknik t.tes dengan rumus sebagai

$$
t=\frac{M k-M e}{\sqrt{N(N-1)}}
$$

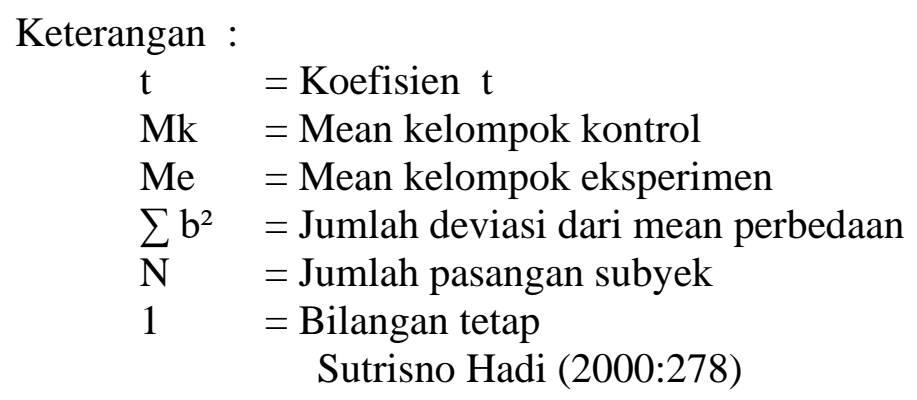

Indikator pengukuran yang digunakan untuk menguji kebenaran hipotesis penelitian ini adalah apabila nilai $\mathrm{t}$ hitung yang diperoleh lebih tinggi (lebih besar) dari pada nilai $\mathrm{t}$ tabel, maka hipotesis nihil $\left(\mathrm{H}_{0)}\right.$ ditolak yang berarti penerimaan hipotesis alternatif $\left(\mathrm{H}_{\mathrm{i}}\right)$. Sebaliknya apabila nilai t hitung lebih kecil dari pada nilai t tabel, maka hipotesis nihil (Ho) diterima, yang berarti bahwa ada perbedaan antara prestasi belajar siswa yang diajar dengan menggunakan media gambar dengan prestasi belajar siswa yang diajar dengan tidak menggunakan media gambar siswa 
kelas X dalam mata pelajaran Kewarganegaraan di SMA Negeri 4 Polewali Kabupaten Polewali Mandar.

\section{Hasil}

Data rata-rata prestasi siswa kelas eksperimen dan kelas kontrol hasil tes sebanyak tiga kali sebagai berikut :

\begin{tabular}{|c|c|c|c|}
\hline \multirow{3}{*}{ No } & Pasangan Subyek & \multicolumn{2}{|c|}{ Rata-rata Prestasi Belajar } \\
\hline & $\mathrm{K}-\mathrm{E}$ & Kelas kontrol & Kelas Eksperimen \\
\hline & 1 & 2 & 3 \\
\hline 1 & $1-36$ & 60.67 & 70.83 \\
\hline 2 & $2-37$ & 70.67 & 80.00 \\
\hline 3 & $3-38$ & 60.33 & 70.67 \\
\hline 4 & $4-39$ & 60.33 & 80.67 \\
\hline 5 & $5-40$ & 60.00 & 80.67 \\
\hline 6 & $6-41$ & 60.67 & 80.53 \\
\hline 7 & $7-42$ & 70.17 & 80.33 \\
\hline 8 & $8-43$ & 70.83 & 80.00 \\
\hline 9 & $9-44$ & 70.67 & 80.67 \\
\hline 10 & $10-45$ & 80.17 & 70.87 \\
\hline 11 & $11-46$ & 70.50 & 70.83 \\
\hline 12 & $12-47$ & 80.00 & 70.00 \\
\hline 13 & $13-48$ & 70.50 & 70.67 \\
\hline 14 & $14-49$ & 70.50 & 60.67 \\
\hline 15 & $15-50$ & 70.50 & 70.00 \\
\hline 16 & $16-51$ & 60.00 & 80.33 \\
\hline 17 & $17-52$ & 60.33 & 90.00 \\
\hline 18 & $18-53$ & 50.33 & 80.83 \\
\hline 19 & $19-54$ & 70.17 & 80.00 \\
\hline 20 & $20-56$ & 60.00 & 80.83 \\
\hline 21 & $21-57$ & 70.50 & 80.83 \\
\hline 22 & $22-58$ & 70.50 & 90.33 \\
\hline 23 & $23-58$ & 70.00 & 90.50 \\
\hline 24 & $24-59$ & 70.00 & 90.67 \\
\hline 25 & $25-60$ & 70.33 & 90.67 \\
\hline 26 & $26-61$ & 70.17 & 80.67 \\
\hline 27 & $27-62$ & 70.33 & 80.83 \\
\hline 28 & $28-63$ & 70.00 & 80.00 \\
\hline 29 & $29-64$ & 70.67 & 70.67 \\
\hline 30 & $30-65$ & 70.50 & 70.67 \\
\hline 31 & $31-66$ & 60.33 & 90.33 \\
\hline 32 & $32-67$ & 60.33 & 80.17 \\
\hline 33 & $33-68$ & 60.83 & 80.50 \\
\hline 34 & $34-69$ & 60.17 & 80.67 \\
\hline 35 & $35-70$ & 50.33 & 80.33 \\
\hline & Rata-rata & 60.95 & 80.35 \\
\hline
\end{tabular}


Dari hasil tes sebanyak tiga kali, baik terhadap kelas eksperimen maupun kelas kontrol terdapat hasil rata-rata prestasi belajar siswa yang berbeda secara signifikan. Rata-rata prestasi belajar siswa kelompok eksperimen adalah 80,35 sedangkan prestasi belajar siswa kelompok kontrol adalah rata-rata 60,95. Berdasarkan analisis data diperoleh Nilai $t$ adalah 6,825 nilai $t$ tersebut dibandingkan dengan nilai t tabel pada taraf kepercayaan $5 \%$ pada $\mathrm{db}=69(\mathrm{Nx}+\mathrm{Ny}-1$ ) atau $35+35-1=69$ untuk menguji hipotesis penelitian. Karena tidak ada db 69, maka diambil $\mathrm{db}$ yang lebih mendekati yaitu $\mathrm{db}=60$. Nilai t tabel pada taraf kepercayaan $5 \%$ adalah 2,000 ( nilai t hitung lebih besar dari pada nilai $\mathbf{t}$ tabel). Dari kriteria penerimaan dan penolakan hipotesis maka hasil akhir analisis data di atas membuktikan bahwa hipotesis penelitian yang berbunyi :

Ada perbedaan prestasi belajar siswa kelas $\mathrm{X}$ yang diajar dengan menggunakan media gambar dengan prestasi belajar siswa yang yang diajar tanpa menggunakan media gambar dalam mata pelajaran Kewarganegaraan di SMA Negeri 4 Polewali kabupaten Polewali Mandar diterima pada taraf kepercayaan $5 \%$.

\section{Pembahasan}

Penelitian ini memberikan gambaran bahwa pengajaran dalam mata pelajaran Kewarganegaraan yang dianggap menjenuhkan, dengan menggunakan media gambar akan lebih efektif, menarik perhatian siswa, membantu siswa memfokuskan perhatian serta memberikan penguatan materi. Dari hasil analisis data terbukti bahwa prestasi belajar siswa yang menggunakan media gambar prestasi belajarnya lebih tinggi dari pada prestasi belajar siswa yang tidak menggunakan media gambar. Terjadinya peningkatan prestasi belajar siswa dalam pengajaran oleh karena media gambar membantu siswa dalam melihat secara nyata tentang apa yang dijelaskan. Penjelasan guru tidak berlansung secara teoretis tetapi nampak dalam gambar meskipun gambar diam. Guru akan terbantu dalam penyampaian pesan lewat gambar sedangkan siswa terbantu memahami konsep yang dijelaskan oleh guru. Artinya bahwa antara guru dengan siswa terjadi interaksi timbal balik yang terespon positif. Penggunaan media gambar, membuat siswa terbantu memahami hal-hal yang tidak dapat terungkapkan melalui penjelasan guru. Dengan demikian maka penggunakan media gambar bagan struktur pemerintahan pada materi Pengertian Negara dan Unsur-unsur terbentuknya Negara efektif. Hal ini terlihat dari rata-rata prestasi belajar siswa kelas eksperimen yaitu 80,35 sedangkan kelas kontrol adalah 60,95.

\section{Kesimpulan}

Berdasarkan hasil analisis data diperoleh rata-rata prestasi belajar siswa kelompok eksperimen adalah 80,35 sedangkan prestasi belajar siswa kelompok kontrol adalah rata-rata 60,95 dengan nilai t hitung 6,825 lebih besar dari nilai t tabel sebesar 2,000 pada taraf kepercayaan $5 \%$, sehingga hipotesis diterima yang berarti bahwa ada perbedaan antara prestasi belajar siswa yang diajar dengan media gambar dengan prestasi belajar siswa yang diajar dengan tidak menggunakan media gambar pada mata pelajaran Kewarganegaraan kelas X di SMA Negeri 4 Polewali Kabupaten Polewali Mandar.

Pengajaran Kewarganegaraan dengan menggunakan media gambar terbukti lebih efektif dalam meningkatkan prestasi belajar siswa karena dengan menggunakan media gambar siswa dapat menyaksikan gambaran secara nyata materi yang diajarkan sehingga siswa termotivasi untuk belajar yang pada akhirnya dapat meningkatkan prestasi belajarnya. 


\section{Referensi}

Amir Hamzah Sulaiman. 1988 Media audio visual. Jakarta : PT. Gramedia Jakarta

Arif Sadiman. 1993. Media Pendidikan. Jakarta : Raja Grapindo Persada.

Aristo Rahadi,2003,Media Pembelajaran,Jakarta,Dirjen Depdiknas RI.

Bona Frans. 1986. Cara Belajar Efisien. Yokyakarta : Gajah Mada. Universitas Press.

Danim. 1993. Media Kurikulum Pendidikan : Jakarta : Bumi Aksara

Muhammad Ali . 1983 Guru Dalam Proses Belajar Mengajar. Bumi Siliwangi : Sinar baru algensindo.

Nana Sudjana. 1990. Media Pengajaran. Bandung : Sinar Baru

Oemar Hamalik. 1989. Media Pendidikan. Bandung : PT. Citra Aditya Bakti.

Sewang, A., \& Mustafa, T. (2020). Peningkatan Teacher Skills melalui Supervisi Klinis dengan Pendekatan Kooperatif Learning. Indonesian Journal of Educational Science (IJES), 3(1), 49-68.

Slameto, 1991. Belajar dan Faktor-Faktor Yang Mempengaruhinya. Jakarta: Rineka Cipta.

Soetinah Soewondo, 1980. Audio Visual Aids : Ujung Pandang IKIP.

Suharsimi Arikunto. 1993. Media Pengajaran. Bandung : CV Sinar Baru

Suherman. 1992. Strategi Belajar Mengajar. Jakarta : PT Rineka Cipta

Sutrisno Hadi. 2000 Statistik II. Yogyakarta : Andi Off set.

Tutu, Mustapa. (2021). Improving Civics Learning Achievement Through Giving Initial Assignments in State High Schools. JED (Journal of Etika Demokrasi), 6(2), 264-271.

Tutu, Mustapa. (2019). Meningkatkan Hasil Belajar Pendidikan Kewarganegaraan Melalui Penerapan Model Pembelajaran Kooperatif Tipe Think Pair Share Siswa Sekolah Menengah Atas Negeri 4 Polewali Mandar Provinsi Sulawesi Barat. JED (Journal of Etika Demokrasi), 4(2).

Winarno Surakhmad. 1985. Pengatar Penelitian Ilmiah. Bandung : Tarsito. 